\title{
Body size overlap in industrial and artisanal fisheries for five commercial fish species in the Mediterranean Sea*
}

\author{
KONSTANTINOS I. STERGIOU ${ }^{1}$, DIMITRIOS K. MOUTOPOULOS ${ }^{1}$ \\ and GEORGIOS KRASSAS ${ }^{2}$ \\ ${ }^{1}$ Aristotle University of Thessaloniki, School of Biology, Department of Zoology, Laboratory of Ichthyology, BOX 134, \\ 54124 Thessaloniki, Greece. E-mail: kstergio@bio.auth.gr \\ ${ }^{2}$ Fisheries Department of Naxos, Chora Naxou, 84300, Naxos, Greece
}

\begin{abstract}
SUMMARY: In this study we present the length frequency distributions of Boops boops, Mullus barbatus, Scomber japonicus, Spicara smaris and Trachurus mediterraneus caught with different gears (trawls, purse-seines, beach-seines, gill nets, trammel nets and longlines) in Cyclades during 1995-2000. Trawls generally caught the smallest sizes for four out of the five species studied (i.e. B. boops, M. barbatus, S. smaris and T. mediterraneus) and purse-seines caught individuals with intermediate sizes between those caught with trawls and small-scale gears. For S. japonicus, gill nets caught smaller individuals than those caught with purse-seines and trammel nets. The same general pattern was also observed comparing the seasonal length frequencies of the three most abundant species (i.e. B. boops, T. mediterraneus and S. smaris). Generally, trawls caught immature individuals when compared to small-scale gears and the vast majority of the individuals caught by all gears (with the exception of trammel nets for $M$. barbatus) was smaller than the optimum exploitation size, indicating that the gears examined are not appropriate for the sustainable exploitation of these resources.
\end{abstract}

Key words: length frequency distributions, artisanal and industrial gears, E Mediterranean, Aegean Sea.

RESUMEN: SOlAPAMIENTO DE TALLAS EN LA PESQUERÍA INDUSTRIAL Y ARTESANAL DE CINCO ESPECIES DE PECES COMERCIALES en el MAR MEDITERRÁNEO. - En este estudio presentamos la distribución de frecuencia de tallas de Boops boops, Mullus barbatus, Scomber japonicus, Spicara smaris y Trachurus mediterraneus capturados con diferentes artes de pesca (arrastre, cerco, artes de playa, redes de enmalle, trasmallos y palangres) en las islas Cícladas, en el periodo 1995-2000. Los arrastreros capturan, generalmente, las tallas mas pequeñas de cuatro de las cinco especies estudiadas (B. boops, M. barbatus, $S$. smaris y T. mediterraneus) mientras que el cerco captura individuos de tallas intermedias entre las capturadas por el arrastre y los artesanales. En el caso de S. japonicus, los artes de enmalle capturan individuos más pequeños que los capturados por el cerco y el trasmallo. El mismo patrón general se observó comparando la frecuencia de tallas estacional de las tres especies mas abundantes (B. boops, T. mediterraneus y $S$. smaris). Generalmente el arrastre captura individuos inmaduros cuando se compara con los artes artesanales y la mayoría de los individuos capturados por todos los artes (con la excepción del trasmallo para $M$. barbatus) son mas pequeños que la talla óptima de explotación, indicando que los artes de pesca examinados no son apropiados para la explotación sostenible de estos recursos.

Palabras clave: distribución de frecuencia de tallas, artes de pesca artesanales e industriales, Mediterráneo oriental, mar Egeo.

\section{INTRODUCTION}

Body length is the most important biological parameter, which apart from a plethora of other bio-

*Received July 25, 2002. Accepted September 10, 2003. logical parameters (e.g., longevity and mortality: Pauly, 1980; predator-prey length relationship: Cohen et al., 1993; trophic level: Froese and Pauly, 2002, FishBase online, www.fishbase.org; Pauly et al., 1998a, b; Stergiou and Karpouzi, 2002; fecundity and reproductive success: Ebenman and Persson, 
1988; body girth: Stergiou and Karpouzi, 2003) is also related to a variety of fishery parameters (e.g. management risk and landing variability: Stergiou, 1998; discard rate: Machias et al., 2001; optimum exploitation length $\mathrm{L}_{\mathrm{opt}}$ : Froese and Binohlan, 2000). Length is also commonly used in fisheries science because it is very easy to measure in comparison with other parameters, such as weight, and there are long and continuous length time-series in most fishery institutes (Pauly and Morgan, 1987). Finally, length frequency distributions are used for the estimation of size selectivity for different gears (e.g. Millar and Fryer, 1999). The latter is important for estimating gear overlap in terms of body sizes in order to identify and separate gear-specific imposed mortality rates (Chopin et al., 1996).

Fisheries in the Mediterranean Sea are strongly multi-species and multi-gear in nature, with many species, ranging in length from a few centimeters to more than $1 \mathrm{~m}$, being exploited by different gears. Nowadays, there is an increased interest in small-scale fisheries, generally practiced with set gears, and the potential partial replacement of trawl nets by set gears, which are generally more selective, might be beneficial to fisher's livelihoods (Fabi et al., 2002). Despite the large number of studies concerning single-gear size-selectivity aspects (see reviews by: Hamley, 1975; Lokkeborg and Bjordal, 1992; Millar and Fryer, 1999), few comparative studies have so far been carried out on size comparisons of species exploited by both industrial and artisanal fisheries (Table 1). Such information is generally lacking for the eastern Mediterranean Sea.

In the present study we compared the length frequency distributions of five commercial fish species (Boops boops, Mullus barbatus, Scomber japonicus, Spicara smaris and Trachurus mediterraneus) caught with trawls, purse-seines, beach-seines, trammel nets, gill nets and longlines in the Aegean Sea (Cyclades). The five species studied abound in the study area, contributing more than $57 \%$ to the total mean landings during 1982-1997 (Stergiou et al., 1997). In addition, the length-frequencies were also compared against optimum exploitation length $\left(\mathrm{L}_{\text {opt }}\right)$, length at $50 \%$ maturity $\left(\mathrm{L}_{50}\right)$ and minimum landing size (MLS). All the above mentioned comparisons were used to identify potential gear overlap and competition, as well as the suitability of the different gears for sustainable exploitation.

\section{MATERIALS AND METHODS}

Stratified random samples of Boops boops, Mullus barbatus, Spicara smaris, Scomber japonicus and Trachurus mediterraneus were collected monthly (50 specimens per month) from the commercial landings of one trawl (nominal mesh size: $14 \mathrm{~mm}$ bar length), one purse seine (nominal mesh size: 8 $\mathrm{mm}$ bar length) and one beach-seine (nominal mesh size: $8 \mathrm{~mm}$ bar length) in the fishing ports of Naxos Island (Fig. 1) from September 1995 to December 1997. Consequently, in the laboratory individual fish

TABLE 1. - Comparative studies concerning size comparisons for different species and gears (T, trawls; B, beach seines; G, gill nets; TN, trammel nets; and L, longlines).

\begin{tabular}{|c|c|c|c|c|c|}
\hline Study area & Year & Gear used & Study species & Aim of study & Author \\
\hline West Greenland & $1987-1989$ & $\mathrm{~L}, \mathrm{~T}$ & Gadus morhua & $\begin{array}{l}\text { Size and species } \\
\text { selectivity }\end{array}$ & $\begin{array}{l}\text { Hovgard and Riget } \\
\text { (1992) }\end{array}$ \\
\hline Greenland & 1994 & $\mathrm{G}, \mathrm{L}, \mathrm{T}$ & $\begin{array}{c}\text { Reinhardtius } \\
\text { hippoglossoides }\end{array}$ & Size selectivity & Huse et al. (1999) \\
\hline Barents Sea & 1992 & $\mathrm{G}, \mathrm{L}, \mathrm{T}$ & $\begin{array}{l}\text { Reinhardtius } \\
\text { hippoglossoides }\end{array}$ & $\begin{array}{l}\text { Size and species } \\
\text { selectivity }\end{array}$ & $\begin{array}{l}\text { Nedreaas et al. } \\
\text { (1996) }\end{array}$ \\
\hline North Norway & 1996 & $\mathrm{G}, \mathrm{L}, \mathrm{T}_{N}$ & $\begin{array}{c}\text { Gadus morhua and } \\
\text { Melanogrammus aeglefinus }\end{array}$ & $\begin{array}{l}\text { Size and species } \\
\text { selectivity }\end{array}$ & Huse et al. (2000) \\
\hline Baltic Sea & 1993 & $\mathrm{G}, \mathrm{T}$ & All species caught & $\begin{array}{l}\text { Size and species } \\
\text { selectivity }\end{array}$ & Lowry et al. (1994) \\
\hline Rockall Trough, and Porcupine Bank (NE Atlantic & ic) 1995 & $\mathrm{~L}, \mathrm{~T}$ & All species caught & $\begin{array}{l}\text { Size and species } \\
\text { selectivity }\end{array}$ & $\begin{array}{c}\text { Connolly and Kelly } \\
\text { (1996) }\end{array}$ \\
\hline Emerald and LaHave (Scotian Shelf) & 1991 & ${ }^{\mathrm{L}, \mathrm{T}} N$ & $\begin{array}{l}\text { Gadus morhua and } \\
\text { Melanogrammus aeglefinus }\end{array}$ & is Size selectivity & Halliday (2002) \\
\hline Western Mediterranean & $1993-1994$ & $\mathrm{TN}, \mathrm{T}$ & Mullus barbatus & $\begin{array}{l}\text { Size and species } \\
\text { selectivity }\end{array}$ & $\begin{array}{c}\text { Demestre et al. } \\
\text { (1997) }\end{array}$ \\
\hline Gulf of Lions & 1988 & $\mathrm{G}, \mathrm{TN}, \mathrm{T}$ & Merluccius merluccius & Species selectivity & $\begin{array}{l}\text { Aldebert et al. } \\
\text { (1993) }\end{array}$ \\
\hline Eastern Mediterranean (Aegean Sea) & 1992 & $\mathrm{G}, \mathrm{TN}, \mathrm{B}$ & All species caught & $\begin{array}{l}\text { Size and species } \\
\text { selectivity }\end{array}$ & Stergiou et al. (1996) \\
\hline Sydney (NSW Australia) & $1989-1993$ & $\mathrm{~L}, \mathrm{~T}$ & Pagrus aurata & Size selectivity & Otway et al. (1996) \\
\hline
\end{tabular}




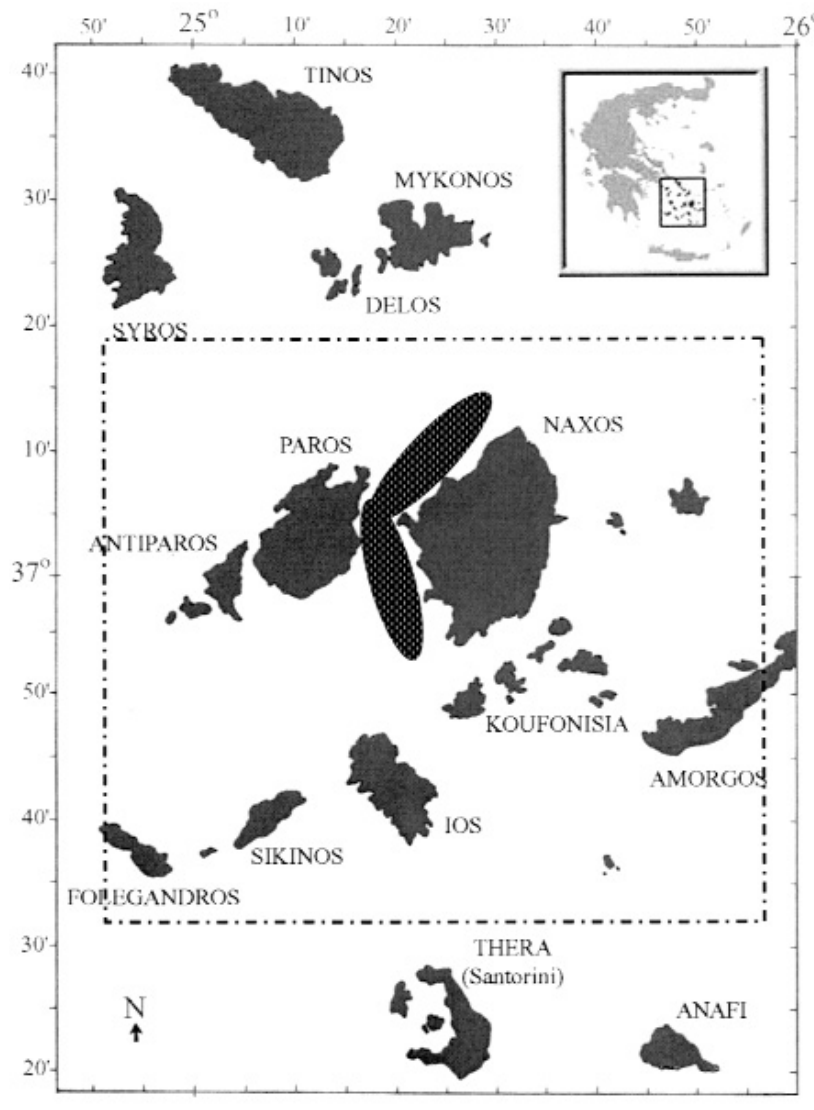

FIG. 1. - Sampling area. The shaded area indicates the fishing grounds sampled by beach-seines, gill nets, trammel nets and longlines and the box covers the trawl and purse-seine fishing grounds.

were measured for fork length (FL, in $\mathrm{cm})$. Samples were not collected for trawls and beach-seines during the period from 1 June to 30 September, and for purse-seines from 10 December to the end of February, because fishing with these gears is prohibited during these periods.

Samples of four out of five species (i.e. B. boops, M. barbatus, S. japonicus and T. mediterraneus) were also collected experimentally with trammel nets (nominal inner mesh sizes: 20, 24 and $28 \mathrm{~mm}$, bar length), gill nets (nominal mesh sizes: 22, 24, 26 and $28 \mathrm{~mm}$, bar length) and longlines (Mustad hook sizes: $11>12>13>15$ ) using a chartered commercial small-scale vessel operating from October 1997 to October 1998 for gill nets (42 trials) and longlines (43 trials) and from October 1999 to September 2000 for trammel nets (41 trials). Sampling sites were selected by the fisher in the traditional local fishing grounds. More details on gear construction and sampling are given elsewhere (Stergiou et al., 2001; Stergiou et al., 2002; Stergiou and Erzini, 2002). Consequently, individual fish were measured for total length (TL, in $\mathrm{cm}$ ). For the purposes of this study, the lengths of all five study species were expressed as TL (in $\mathrm{cm}$ ), using the equations from Moutopoulos and Stergiou (2002).

Length frequency distributions were constructed for all species per gear, and for the three most abundant species (i.e. B. boops, T. mediterraneus and $S$. smaris) separately by season. Comparisons of length frequency distributions by different gears and seasons were carried out using the KolmogorovSmirnov test (Zar, 1999). In addition, Schoener's overlap index (1970), which is used for estimating niche overlap $(T)$, was used here to estimate overlap in terms of length classes between different gears:

$$
T=1-0.5 \sum_{i=1}^{n}\left|P_{x i}-P_{y i}\right|,
$$

where $P_{x i}$ and $P_{y i}$ are ratios, in terms of numbers, of each length class $i$ between two different gears $x$ and $y$. The value of the index ranges from 0 when there is no overlap in length classes between the two gears to 1 when there is a complete overlap between the two gears. The degree of overlap is considered to be important when $T$ values are greater than 0.6 (Schoener, 1970).

Length frequencies per gear were also compared against the mean length at $50 \%$ maturity $\left(\mathrm{L}_{50}\right)$, the optimum exploitation length $\left(\mathrm{L}_{\text {opt }}\right)$ and the minimun landing size (MLS). The mean $\mathrm{L}_{50}$ of the five species studied was extracted from FishBase (Froese and Pauly, 2002) for all species except for T. mediterraneus, for which the value reported for Saronikos Gulf (Karlou-Riga, 1995) was used. The MLS values were taken from the EU Regulation 1626/1994. Finally, $\mathrm{L}_{\text {opt }}$ was estimated from the $\mathrm{L}_{\mathrm{oo}}$ reported in Greek waters taken from Stergiou et al. (1997) using the empirical formula of Froese and Binohlan (2000). All the above mentioned parameters are shown in Table $2 . \mathrm{L}_{50}, \mathrm{~L}_{\mathrm{opt}}$ and MLS were all expressed in TL (in $\mathrm{cm}$ ).

TABLE 2. $-\mathrm{L}_{\infty}$ (in cm), $\mathrm{L}_{50}$ (length at $50 \%$ maturity, in $\mathrm{cm}$ ), $\mathrm{L}_{\mathrm{opt}}$ (optimum exploitation length, in $\mathrm{cm}$ ) and MLS (minimum landing size, in $\mathrm{cm}$ ) of the five species examined.

\begin{tabular}{lcccc}
\hline Species & $\mathrm{L}_{\infty}{ }^{1}$ & $\mathrm{~L}_{50}{ }^{2}$ & $\mathrm{~L}_{\mathrm{opt}}{ }^{3}$ & $\mathrm{MLS}^{4}$ \\
\hline Boops boops & 33.9 & 19.8 & 20.9 & 11.0 \\
Mullus barbatus & 21.5 & 13.1 & 13.0 & 11.0 \\
Scomber japonicus & 55.4 & 30.7 & 34.9 & 18.0 \\
Spicara smaris & 21.0 & 12.9 & 12.7 & 11.0 \\
Trachurus mediterraneus & 39.9 & 20.0 & 24.8 & 12.0 \\
\hline
\end{tabular}

${ }^{1}$ from Stergiou et al. (1997)

${ }^{2}$ from www.fishbase.org

${ }^{3}$ estimated from the $\mathrm{L}_{\infty}$ reported in Greek waters (values taken from Stergiou et al., 1997) using the empirical formula of Froese and Binohlan (2000)

${ }^{4}$ from EU Regulation 1626/1994. 
TABLE 3. - Descriptive statistics of total length (TL, in cm) for each species in each different gear, Cyclades 1995-2000. N is the number of individuals; Mean is the average TL; Median is the median TL; Mode is the number of main modes in length-frequencies; Minimum and Maximum are the minimum and maximum TL; SE is the standard error of TL; $\% \mathrm{~L}_{50}$ is the percentage of individuals with TL smaller than the length at $50 \%$ maturity $\left(\mathrm{L}_{50}\right)$; and $\% \mathrm{~L}_{\mathrm{opt}}$ is the percentage of individuals with TL smaller than optimum exploitation length $\left(\mathrm{L}_{\mathrm{opt}}\right)$.

\begin{tabular}{|c|c|c|c|c|c|c|c|c|c|}
\hline Species/Gear & $\mathrm{N}$ & Mean & Median & Mode & Minimum & Maximum & SE & $\% \mathrm{~L}_{50}$ & $\% \mathrm{~L}_{\mathrm{opt}}$ \\
\hline \multicolumn{10}{|l|}{ Boops boops } \\
\hline Purse-seines & 947 & 18.1 & 17.9 & 1 & 11.8 & 27.1 & 0.077 & 78.2 & 86.5 \\
\hline Trawls & 782 & 15.5 & 15.4 & 1 & 10.4 & 22.0 & 0.074 & 97.2 & 99.0 \\
\hline Trammel nets & 522 & 19.8 & 19.7 & 1 & 11.5 & 26.3 & 0.097 & 50.4 & 72.6 \\
\hline Gill nets & 106 & 21.7 & 22.0 & 2 & 14.5 & 28.1 & 0.204 & 14.2 & 25.5 \\
\hline Longlines & 18 & 22.1 & 22.4 & 1 & 16.6 & 25.7 & 0.548 & 11.1 & 27.8 \\
\hline \multicolumn{10}{|l|}{ Mullus barbatus } \\
\hline Trawls & 836 & 14.9 & 14.9 & 2 & 10.7 & 22.7 & 0.063 & 16.3 & 15.3 \\
\hline Trammel nets & 184 & 18.3 & 18.5 & 1 & 13.1 & 23.1 & 0.119 & 0.0 & 0.0 \\
\hline Gill nets & 15 & 20.6 & 20.7 & 1 & 19.1 & 22.5 & 0.238 & 0.0 & 0.0 \\
\hline \multicolumn{10}{|c|}{ Scomber japonicus } \\
\hline Purse-seines & 519 & 26.2 & 26.0 & 1 & 21.3 & 32.8 & 0.093 & 98.7 & 100.0 \\
\hline Trammel nets & 54 & 28.0 & 28.4 & 1 & 23.1 & 33.8 & 0.321 & 88.9 & 100.0 \\
\hline Gill nets & 71 & 25.7 & 25.1 & 1 & 22.9 & 33.0 & 0.244 & 97.2 & 100.0 \\
\hline \multicolumn{10}{|l|}{ Spicara smaris } \\
\hline Trawls & 833 & 12.1 & 11.6 & 1 & 5.8 & 17.0 & 0.056 & 72.4 & 71.9 \\
\hline Beach-seines & 636 & 13.0 & 12.8 & 1 & 6.7 & 17.7 & 0.071 & 51.1 & 48.3 \\
\hline \multicolumn{10}{|c|}{ Trachurus mediterraneus } \\
\hline Purse-seines & 576 & 22.3 & 22.0 & 1 & 12.4 & 32.2 & 0.111 & 21.2 & 79.7 \\
\hline Trawls & 313 & 17.7 & 18.2 & 1 & 12.8 & 24.2 & 0.125 & 91.4 & 100.0 \\
\hline Trammel nets & 355 & 24.1 & 23.7 & 1 & 18.3 & 33.7 & 0.121 & 0.6 & 66.2 \\
\hline Gill nets & 194 & 24.9 & 24.6 & 1 & 17.3 & 34.1 & 0.209 & 3.6 & 53.6 \\
\hline
\end{tabular}
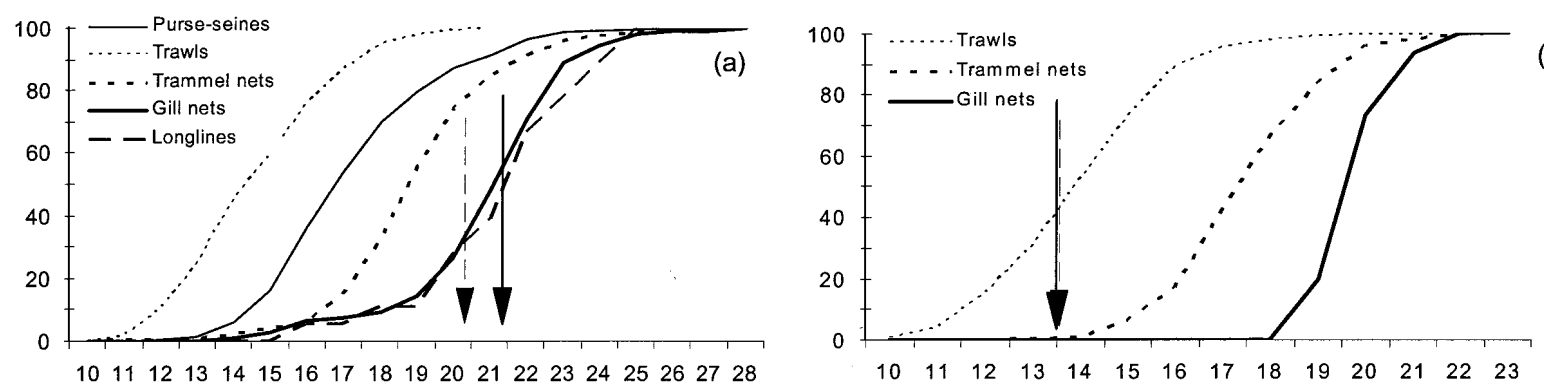

(b)
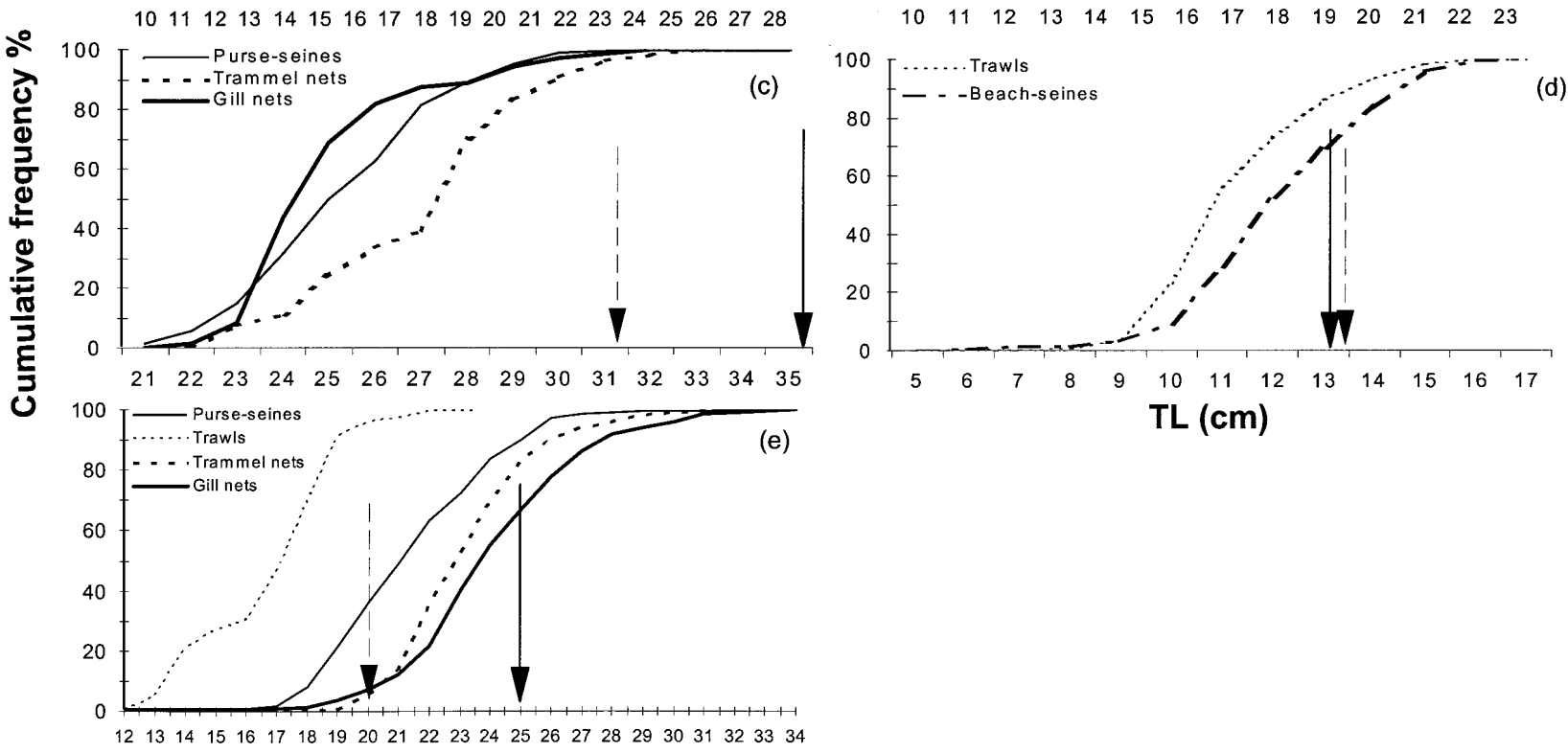

TL $(\mathrm{cm})$

FIG. 2. - Cumulative length frequency distributions for the different gears used for: (a) Boops boops, (b) Mullus barbatus, (c) Scomber japonicus, (d) Spicara smaris and (e) Trachurus mediterraneus, Cyclades, 1995-2000. Dotted arrow indicates the mean length at 50\% maturity $\left(\mathrm{L}_{50}\right)$, whereas the continuous arrow the optimum exploitation length $\left(\mathrm{L}_{\mathrm{opt}}\right)$. 

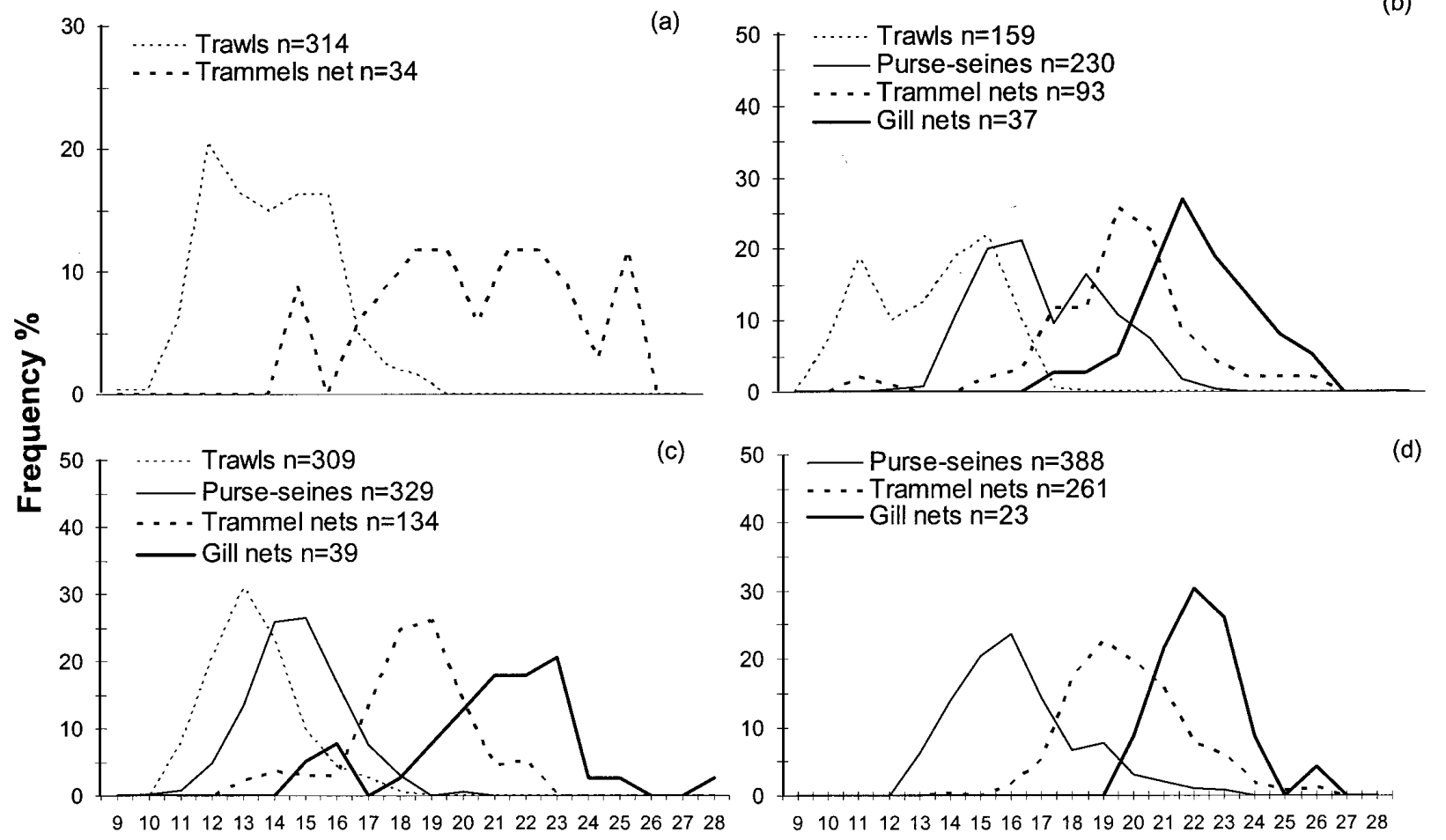

(d)

$\mathrm{TL}(\mathrm{cm})$

FIG. 3. - Seasonal length frequency distributions of Boops boops per gear used in (a) autumn, (b) winter, (c), spring and (d) summer, Cyclades, 1995-2000; $\mathrm{n}=$ numbers of individuals.

\section{RESULTS}

The length characteristics of the five species studied are shown in Table 3. B. boops was collected with all gears except beach-seines. $M$. barbatus was collected with trawls, gill nets and trammel nets, $S$. japonicus with purse-seines, gill nets and trammel nets, $S$. smaris with trawls and beach-seines and T. mediterraneus with purse-seines, trawls, gill nets and trammel nets. The cumulative length frequency distributions (Fig. 2) revealed that for all species trawls caught smaller individuals than all other gears (Table 3, Fig. 2). Thus, the median length of the four above-mentioned species caught with trawls were 15.4, 14.9, 11.6 and $18.2 \mathrm{~cm}$ respectively, compared with the median length of the individuals of the same species caught with the remaining gears that were larger than 17.9, 18.5, 12.8 and $22.0 \mathrm{~cm}$ respectively (Table 3, Fig. 2). For all species, purse-seines caught individuals with intermediate sizes between those caught with trawls and artisanal gears. For $S$. japonicus, the median length of the individuals caught with gill nets (25.1 $\mathrm{cm}$ ) was smaller than those caught with purse-seines and trammel nets (26.0 and $28.4 \mathrm{~cm}$ respectively) (Table 3, Fig. 2).
The percentage of immature individuals (i.e. those with $\mathrm{TL}<\mathrm{L}_{50}$ ) was greater for trawls in all species caught with this gear (Table 3). It was lower for longlines for B. boops, for nets for M. barbatus and T. mediterraneus, and for beach-seines for $S$. smaris (Table 3 ). The only exception was $S$. japonicus, for which the percentage of immature individuals was very high for all gears studied (for all cases $>88.9 \%$ ). The percentage of individuals with $\mathrm{TL}<$ $\mathrm{L}_{\text {opt }}$ (Table 3), was high for all gears and all species studied (for all cases $>50.0 \%$ ), with the exception of $M$. barbatus for all gears used (i.e., $<15.3 \%$ ) and $B$. boops for nets (i.e. $<27.8 \%$ ).

The application of the Kolmogorov-Smirnov test indicated that for all species the length frequencies differed significantly $(\mathrm{P}<0.001)$ between all pairs of gears, with the exception of the gillnet-longline pair for B. boops $(\mathrm{P}=0.085)$. Size overlap, for $B$. boops, was great between longlines, gill nets and trammel nets and between purse-seines and trammel nets (for all cases: $\mathrm{T}>0.50$ ). For T. mediterraneus and $S$. japonicus, overlap was also great between gill nets, trammel nets and purse-seines (for all cases: $T$ $>0.51)$. Finally, for $S$. smaris there was a great overlap between trawls and beach-seines $(\mathrm{T}=0.72)$, whereas for $M$. barbatus the degree of overlap 


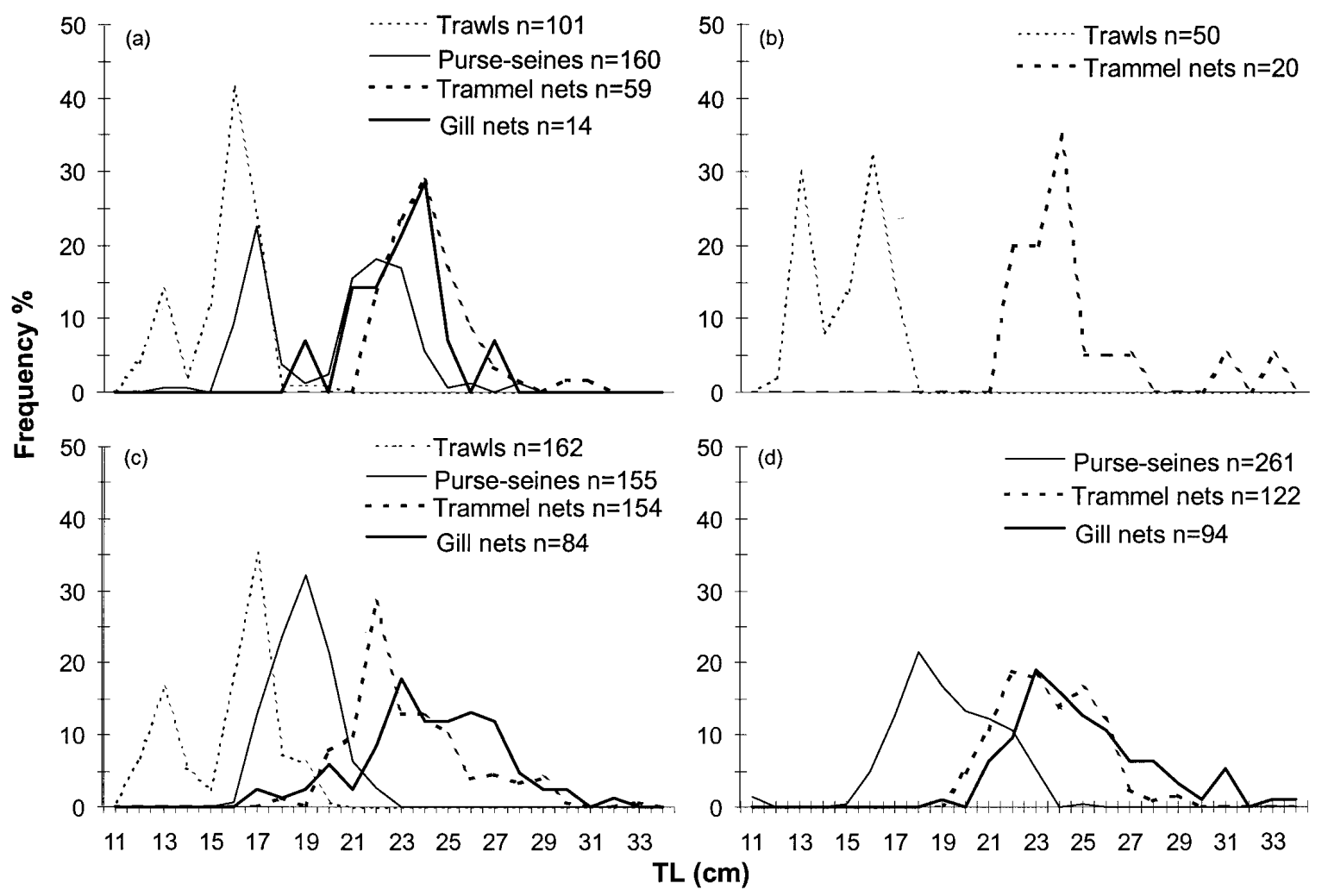

FIG. 4. - Seasonal length frequency distributions of Trachurus mediterraneus per gear used in (a) autumn, (b) winter, (c) spring and (d) summer, Cyclades, 1995-2000; $n=$ numbers of individuals.

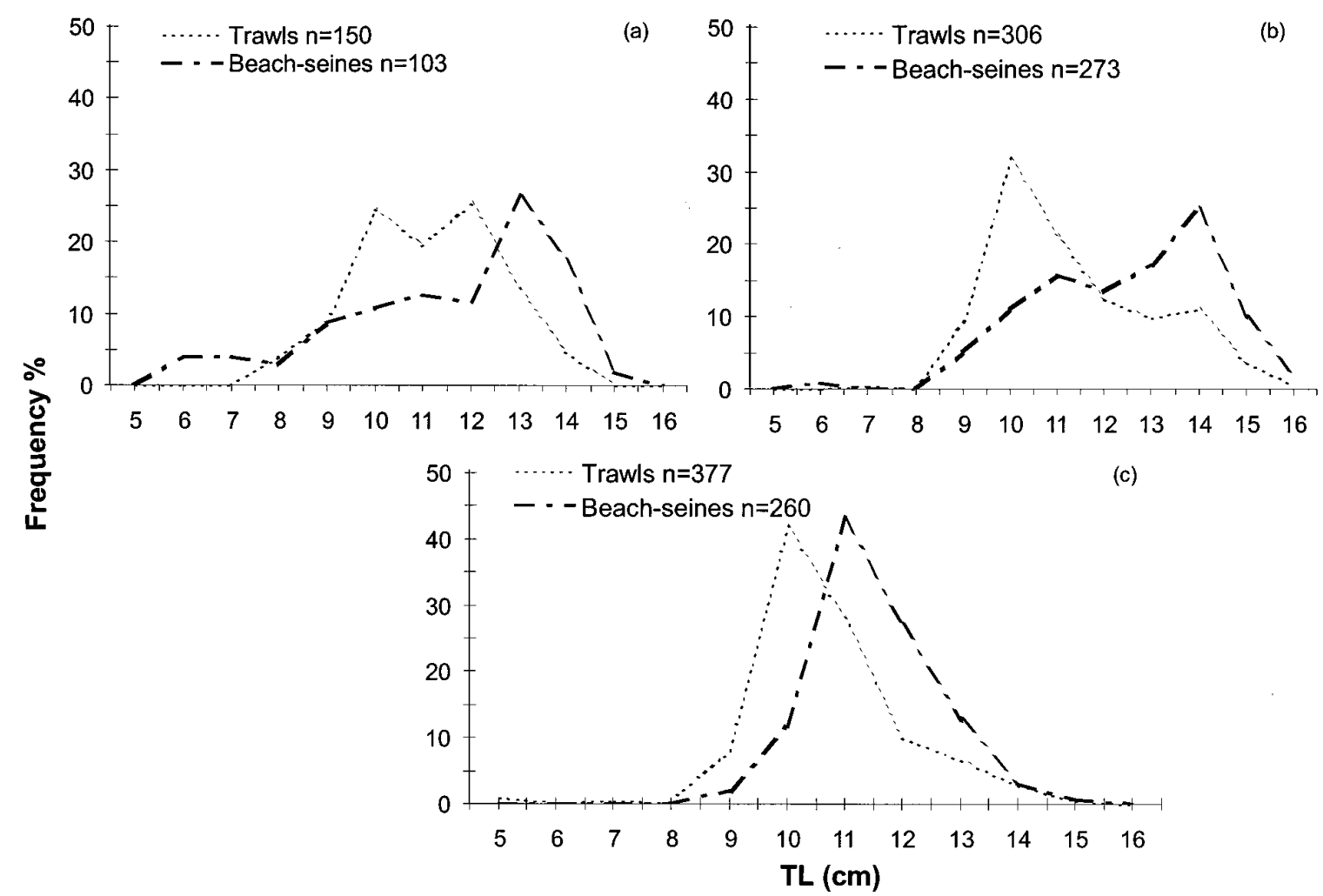

FIG. 5. - Seasonal length frequency distributions of Spicara smaris per gear used in (a) autumn, (b) winter and (c) spring, Cyclades, 19952000; $n=$ numbers of individuals.

184 K.I. STERGIOU et al. 
TABLE 4. - Results of the Kolmogorov-Smirnov test for pairs of length frequency distributions for different gear-season combinations for Boops boops and Trachurus mediterraneus, which did not differ significantly $(\mathrm{P}>0.05)$ for each pair of gear-season combination.

\begin{tabular}{|c|c|c|c|c|c|}
\hline Species & \multicolumn{4}{|c|}{ Gear/Season } & \\
\hline Boops boops & Trammel net & & Gill net & \\
\hline Gill net & Winter & \multirow{2}{*}{\multicolumn{2}{|c|}{ Autumn }} & Spring & Summer \\
\hline Autumn & 0.146 & & & & \\
\hline Spring & 0.361 & \multirow{2}{*}{\multicolumn{2}{|c|}{$\begin{array}{l}0.594 \\
0.183\end{array}$}} & - & \\
\hline Summer & & & & 0.072 & - \\
\hline Trachurus mediterraneus & \multicolumn{4}{|c|}{ Trammel net } & Gill net \\
\hline Trammel net & Autumn & Winter & Spring & Summer & Spring \\
\hline Winter & 0.758 & - & & & \\
\hline Spring & & 0.032 & - & & \\
\hline Summer & & 0.373 & & - & \\
\hline \multicolumn{6}{|l|}{ Gill net } \\
\hline Autumn & 0.188 & 0.425 & 0.825 & 0.299 & \\
\hline Spring & & 0.170 & & & - \\
\hline Summer & 0.073 & 0.303 & & & 0.674 \\
\hline
\end{tabular}

among the different gears was not great (for all cases: $\mathrm{T}<0.33$ ).

The seasonal length frequencies of the three most abundant species, B. boops, $T$. mediterraneus and $S$. smaris, are shown in Figures 3 to 5. In general, for all species in all seasons, trawls caught smaller individuals than the remaining gears. Gill nets caught larger individuals in autumn, winter and spring for B. boops (Fig. 3), and in spring and summer for $T$. mediterraneus (Fig. 4), than the remaining gears, whereas beach-seines caught larger individuals of $S$. smaris (Fig. 5) in all seasons. The application of the Kolmogorov-Smirnov test for all gear (i.e. trawls, purse-seines, beach-seines, gill nets, trammel nets and longlines) and season (autumn, winter, spring and summer) combinations indicated that for $B$. boops and T. mediterraneus the majority of the length frequencies distributions differed significantly $(\mathrm{P}<0.001)$ between all pairs of gear-season combinations, with few exceptions, which are shown in Table 4. Finally, for $S$. smaris the length frequencies differed significantly $(\mathrm{P}<0.001)$ between all pairs of gear-season combinations.

\section{DISCUSSION}

Although the present study suffers from certain limitations (i.e. low number of commercial vessels sampled; small number of individuals examined per gear type and season; different years sampled by different gears), the results show certain consistent patterns. Thus, the results indicated that although significant differences $(\mathrm{P}<0.05)$ were found in the size compositions for the five species (B. boops, M. bar- batus, S. japonicus, S. smaris and T. mediterraneus) caught with trawls, purse-seines, beach-seines, gill nets, trammel nets and longlines, both within and between seasons, a fact indicating that each gear mainly targets a specific part of the stock size structure, there was a great overlap in the sizes caught with the different gears (Fig. 6). In addition, most species were caught with more than one gear (i.e. from two to five gears; multi-gear fisheries).

Our results also indicated that in general, trawls caught immature individuals when compared to artisanal gears. This is typical of the Mediterranean Sea, where trawl landings are generally composed of the smallest, immature individuals of a species, with sizes smaller than the MLS that are either discarded or marketed illegally (Stergiou et al., 1997; Machias et al., 2001). In addition, the vast majority of the individuals caught by all gears (with the exception of trammel nets for M. barbatus) had lengths smaller than $\mathrm{L}_{\mathrm{opt}}$, a fact indicating that these gears are not appropriate for sustainable exploitation.

However, the effect of each gear on the different species, and thus on the imposed fishing mortalities, must be evaluated based on their relative participation to the local landings. The total official number of boats registered in Cyclades amounts to 264 boats, $8(3.1 \%)$ of which are trawlers, $13(4.9 \%)$ purse-seiners, $18(6.8 \%)$ beach seiners and 225 $(85.2 \%)$ other small boats of lengths ranging from 3.5 to $15 \mathrm{~m}$ (data from the Department of Fisheries, Prefecture of Cyclades). Forty-seven (47) out of the 225 artisanal boats registered use trammel and gill nets as the main gear. The remaining 178 boats use trammel and gill nets as secondary fishing gears. With respect to landings, both artisanal and industri- 

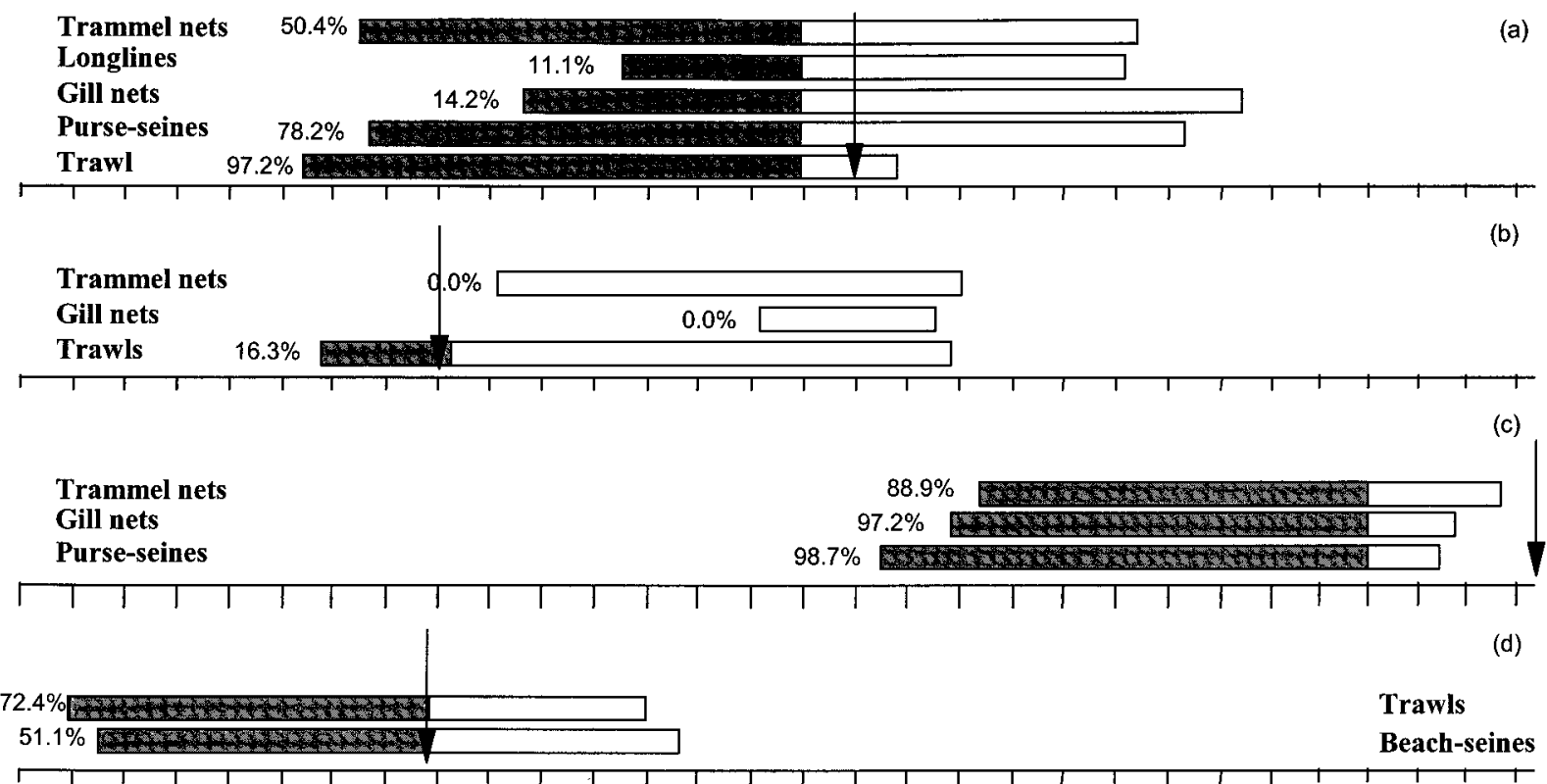

(e)

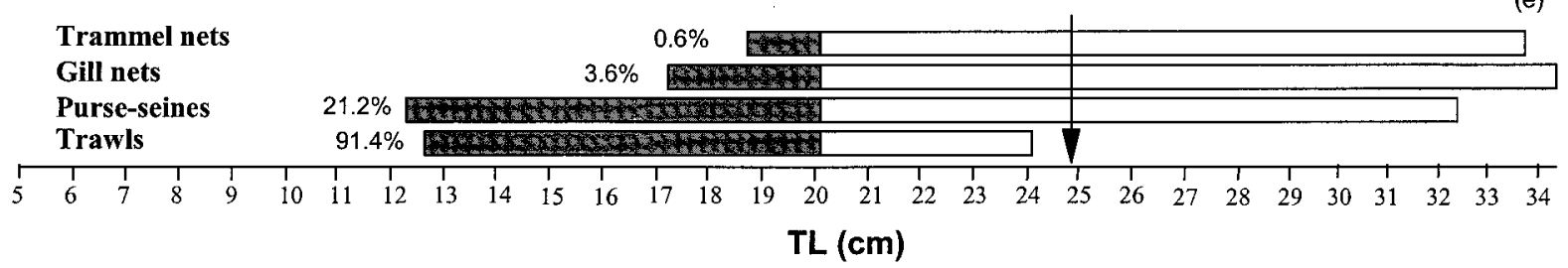

FIG. 6. - Length overlap for different gears used for: (a) Boops boops, (b) Mullus barbatus, (c) Scomber japonicus, (d) Spicara smaris, and (e) Trachurus mediterraneus, Cyclades, 1995-2000. The bar (dark grey and white part) represents the total size range of the species' landings, the dark grey part of the bar indicates immature individuals (i.e. those with TL smaller than $\mathrm{L}_{50}$ ) of each species and the percentages next to each bar indicate the percentage of immature individuals caught with each gear. Arrows denote the optimum exploitation length ( $\left.\mathrm{L}_{\text {opt }}\right)$.

al fisheries share an almost equal proportion. Thus, $52 \%$ of the total reported landings are attributed to the artisanal fisheries (small-scale boats: $34 \%$; beach-seines: $18 \%$ ) and $48 \%$ to the industrial fisheries (purse-seines: 33\%; trawls: 15\%) (NSSH, 1997). In addition, the impact of the industrial gears on fishing mortality for four out of the five species studied (i.e., B. boops, M. barbatus, S. smaris and T. mediterraneus) seems to be more detrimental than artisanal gears, as indicated by the analysis of the mean catch per day of these species (data are not available for S. japonicus; Anon., 2001). Thus, in Cyclades the total mean catch (in $\mathrm{kg}$ ) per day for $B$. boops, M. barbatus, $S$. smaris and T. mediterraneus were $314.6,37.0,208.1$ and $113.7 \mathrm{~kg} /$ day respectively (Anon., 2001). The mean catch per day of $B$. boops and Trachurus spp. was mainly attributed to purse-seines (77.7 and $89.2 \%$ respectively) and for $M$. barbatus and $S$. smaris to trawls and beachseines $(40.2$ and $28.1 \%$; 55.6 and $24.1 \%$ respectively), whereas the mean catch per day of the artisanal gears was comparatively small (for all species: < 14.7\%) (Anon., 2001). It is worthy of mention that the monthly catch per day of the four above-mentioned species in Cyclades declined significantly $(\mathrm{P}$ $<0.05)$ with time during the period 1996-2000 (Anon., 2001), a fact indicating that these species are overfished. Thus, the results of the present study indicated that fishing mortality rates, or the impact of the different gears, most probably differ, with those of industrial fisheries being generally higher.

It must be pointed out that the main effect of the different gears examined is generally concentrated at different fishing grounds (i.e. trawls and purseseines: three nautical miles from the coast or at depths $>50 \mathrm{~m}$; artisanal gears: at depths $<90 \mathrm{~m}$ ) and different seasons (i.e. trawls: from October to May; beach-seines: from October to April; purse-seines: from March to $15^{\text {th }}$ of December; trammel nets, gill nets and longlines: all year round). This fact, combined with the finding that each gear targets to a specific part of the length structure of each stock, indicates that there is no part of the stocks that finds refuge from fishing mortality, either in space or time, with each gear imposing different fishing mortality rates. 
Given the strong multi-species and multi-gear nature of Mediterranean fisheries, which exploit a wide range of species strongly differing in their lifehistories (Stergiou et al., 1997) and thus in their $\mathrm{L}_{\text {opt }}$ and $\mathrm{L}_{50}$, and the difficulties in separating and estimating the different components of fishing mortality (e.g. associated with illegal and misreported landings, artisanal and recreational landings, discards, ghost fishing: Chopin et al., 1996), the use of singlespecies and traditional models for management purposes is not useful. Furthermore, the situation might get more complicated given that many species are characterised by sex-dependant growth rates (Pope et al., 2000). Thus, it is evident that the technical, non-scientific and non-precautionary management measures that are currently in force must be reconsidered and fisheries management must be placed under an ecosystem perspective (e.g. Pauly, 1998; Pitcher et al., 1998; Stergiou, 2002). In general, ecosystem objectives are satisfied by establishing large marine protected areas, where fishing is totally prohibited (Stergiou 2002). Such areas may mediate the rebuilding of highly overfished stocks (Polunin, 2002).

\section{REFERENCES}

Anon. - 2001. Patterns and propensities in Greek fishing effort and catches. Final Technical Report. Institute of Marine Biology of Crete (IMBC) and Aristotle University of Thessaloniki (AUTH), Contract No 00/018, Heraklion, Crete.

Aldebert, Y., L. Recasens and J. Lleonart. - 1993. Analysis of gear interactions in a hake fishery: The case of the Gulf of Lions (NW Mediterranean). Sci. Mar., 57: 207-217.

Cohen, J.E., S.L. Pimm, P. Yodzis and J. Saldana. - 1993. Body sizes of animal predators and animal prey in food webs. $J$. Anim. Ecol., 62: 67-78.

Chopin, F., Y. Inoue, Y. Matsushita and T. Arimoto. - 1996. Development of a catch mortality model. Fish. Res., 25: 377-382.

Connolly, P.L. and C.J. Kelly. - 1996. Catch and discards from experimental trawl and longline fishing in the deep water of the Rockall Trough. J. Fish Biol., 49: 132-144.

Demestre, M., M. Sbrana, F. Alvarez and P. Sanchez. - 1997. Analysis of the interaction of fishing gear in Mullus barbatus fisheries of the Western Mediterranean. J. Appl. Ichth., 13: 49-56.

Ebenman, B. and L. Persson. - 1988. Introduction: Dynamics of size-structured populations: An overview. In: B. Ebenman and L. Persson (eds.), Size-structured populations: ecology and evolution, pp. 3-9. Springer-Verlag.

Fabi, G., M. Sbrana, F. Biagi, F. Grati, I. Leonori and P. Sartor. 2002. Trammel net and gill net selectivity for Lithognathus mormyrus (L., 1758), Diplodus annularis (L., 1758) and Mullus barbatus (L., 1758) in the Adriatic and Ligurian seas. Fish. Res., 54: 375-388.

Froese, R. and C. Binohlan. - 2000. Empirical relationships to estimate asymptotic length, length at first maturity and length at maximum yield per recruit in fishes, with a simple method to evaluate length frequency data. J. Fish Biol., 56: 758-773.

Froese, R. and D. Pauly. - 2002. Fishbase 2002: concepts, design and data sources. Online version: www.fishbase.org.

Halliday, R.G. - 2002. A comparison of size selection of Atlantic cod (Gadus morhua) and haddock (Melanogrammus aeglefinus) by bottom longlines and otter trawls. Fish. Res., 57: 63-73.
Hamley, J.M. - 1975. Review of gillnet selectivity. J. Fish. Res. Board Can., 32: 1943-1969.

Hovgard, H. and F.F. Riget. - 1992. Comparison of longline and trawl selectivity in cod surveys off West Greenland. Fish. Res., 13: 323-353.

Huse, I., A.C. Gundersen and K.H. Nedreaas. - 1999. Relative selectivity of Greenland halibut (Reinhardtius hippoglossoides, Walbaum) by trawls, longlines and gill nets. Fish. Res., 44: 75-93.

Huse, I., S. Lokkeborg and A.V. Soldal. - 2000. Relative selectivity in trawl, longline and gillnet fisheries for cod and haddock. ICES J. Mar. Sci., 57: 1271-1282.

Karlou-Riga, C. - 1995. Biology and dynamics of the Trachurus species (Pisces, Carangidae) in the Saronikos Gulf. $\mathrm{PhD}$ thesis. Aristotle University of Thessaloniki. (In Greek with English abstract).

Lokkeborg, S. and A. Bjordal. - 1992. Species and size selectivity in longline fishing: a review. Fish. Res., 13: 311-322.

Lowry, N., L.H. Knudsen and D.A. Wileman. - 1994. Mesh size experiments in the Baltic cod fishery. Compenhagen Denmark. ICES, ICES-CM-1994/B: 29, Ref. G, 13 pp.

Machias, A., V. Vassilopoulou, D.Vatsos, P. Bekas, A. Kallianiotis, C. Papaconstantinou and N. Tsimenides. - 2001. Bottom trawl discards in the northeastern Mediterranean Sea. Fish. Res., 53: 181-195.

Millar, R. and R. Fryer. - 1999. Estimating the size-selection curves of towed gears, traps, nets and hooks. Rev. Fish Biol. Fish., 9: 89-116.

Moutopoulos, D.K. and K.I. Stergiou. - 2002. Length-weight and length-length relationships of fish species from the Aegean Sea (Greece). J. App. Ichth., 18: 200-203.

Nedreaas, K.H., A.V. Soldal and A. Bjordal. - 1996. Performance and biological implications of a multi-gear fishery for Greenland halibut (Reinhardtius hippoglossoides). J. N. Atl. Fish. Sci., 19: 59-72.

Otway, N.M., J.R. Craig and J.M. Upston. - 1996. Gear-dependent size selection of snapper, Pagrus auratus. Fish. Res., 28: 119-132.

Pauly, D. - 1980. On the interrelationships between natural mortality, growth parameters and mean environmental temperature in 175 fish stocks. J. Cons. Int. Explor. Mer, 39(2): 175-192.

Pauly, D. 1998. - Beyond our original horizons: the tropicalization of Beverton and Holt. Rev. Fish. Biol. Fish., 8: 307-334.

Pauly, D. and T. Morgan. - 1987. Length-based methods in fisheries research. ICLARM Conf. Proc., 13: 468 pp.

Pauly, D., R. Froese and V. Christensen. - 1998b. Response to Caddy et al. How pervasive is fishing down marine food webs? Science, 282: 1384-1386.

Pauly, D., V. Christensen, J. Dalsgaard, R. Froese and J.F. Torres. 1998a. Fishing down marine food webs. Science, 279: 860-863.

Pitcher, T.J., P.J. Hart and D. Pauly. - 1998. Reinventing fisheries management. Chapman \& Hall, London, U.K.

Polunin, N.V.C. - 2002. Marine protected areas, fish and fisheries. In: P.J.B Hart and J.C. Reynolds (eds.), Handbook of Fish and Fisheries, Vol. II. Blackwell, Oxford, $448 \mathrm{pp}$.

Pope, J.G., D.S. MacDonald, N. Daan, J.D. Reynolts and S. Jennings. -2000 . Gauging the impact of fishing mortality on nontarget species. ICES J. Mar. Sci., 57: 689-696.

Schoener, T. -1970 . Non synchronous spatial overlap of lizards in patchy habitats. Ecology, 51: 408-418.

Stergiou, K.I. - 1998. Variability of fish catches in different ecosystems. In: M.E. Durand, P. Cury, R. Mendelssohn, C. Roy, A. Bakun and D. Pauly (eds.), Global versus local changes in upwelling systems, pp. 359-370. ORSTOM Editions, Paris.

Stergiou, K.I. - 2002. Overfishing, tropicalization of fish stocks, uncertainty and ecosystem management: resharpening Ockham's razor. Fish. Res., 55: 1-9.

Stergiou, K.I. and K. Erzini. - 2002. Comparative fixed gear studies in the Cyclades (Aegean Sea): size selectivity of small-hook longlines and monofilaments gill nets. Fish. Res., 58: 25-40.

Stergiou, K.I. and V.S. Karpouzi. - 2002. Feeding habits and trophic levels of Mediterranean fishes. Rev. Fish Biol. Fish., 11: 217-254.

Stergiou, K.I. and V.S. Karpouzi. - 2003. Length-girth relationships for several marine fishes. Fish. Res., 60: 161-168.

Stergiou, K.I., D.K. Moutopoulos and K. Erzini. - 2002. Gill net and longlines fisheries in Cyclades waters (Aegean Sea): species composition and gear competition. Fish. Res., 57: 25-37.

Stergiou, K.I., E.D. Christou, D. Georgopoulos, A. Zenetos and C. Souvermezoglou. - 1997. The Hellenic Seas: Physics, Chem- 
istry, Biology and Fisheries. Oceanog. Mar. Biol. Ann. Rev., 35: 415-538.

Stergiou, K.I., D.K. Moutopoulos, P.K. Karachle, V.S. Karpouzi and K. Erzini. - 2001. Trammel net catch species composition in Cyclades waters (Aegean Sea, Greece). Rapp. Comm. int. Mer Medit., 36: 328.

Stergiou, K.I., G. Petrakis and C.-Y. Politou. - 1996. Small-scale fisheries in the South Euboikos Gulf (Greece): species composition and gear competition. Fish. Res., 26: 325-336.

Zar, J.H. - 1999. Biostatistical Analysis. $4^{\text {th }}$ edition. Prentice-Hall, Englewood Cliffs, New Jersey, 929 pp.

Scient. ed.: P. Sánchez 